https://doi.org/10.15407/frg2019.04.315

UDC 581.143.6

\title{
CELL SELECTION WITH HEAVY METAL IONS FOR OBTAINING SALT TOLERANT PLANT CELL CULTURES
}

\section{L.E. SERGEEVA, S.I. MYKHALSKA}

Institute of Plant Physiology and Genetics, National Academy of Sciences of Ukraine 31/17 Vasylkivska St., Kyiv, 03022, Ukraine

e-mail: mykhalskasvitlana@gmail.com

The cell selection with heavy metal ions was proposed for obtaining salt tolerant plant cell lines. On selective media with the addition of $\mathrm{Ba}^{2+}$ cations resistant soybean and wheat cell variants were obtained. Doses of $\mathrm{Ba}^{2+}$ cations were lethal for wild type cell cultures. The selected clones were tested under stress pressure of various agents: $\mathrm{Ba}^{2+}$ ions, sea water salts, sodium sulfate. Resistant cells sustained any type of lethal stress. Calli retained salt tolerance after cultivation on salt-free medium during several passages. During cultivation under salinity cells demonstrated low $\mathrm{K}^{+} / \mathrm{Na}^{+}$ratios and high free proline accumulation. The $\mathrm{Ba}^{2+}$ provoked opposite cell reactions. It is assumed that combined stress resistance is concerned with realization of different protection mechanisms.

Key words: soybean, wheat, cell selection, $\mathrm{Ba}^{2+}$ cations, salt tolerance.

The theoretical problem of plant stress sensitivity/tolerance attracts attention for its permanent actuality. Contemporary environmental situation is often defines as a combination of abiotic stresses and harmful human activity. Active nutrient absorption and metabolism that ensure plant viability under stress conditions are steady characteristics of tolerant forms. The deficit of plants tolerant to abiotic stresses calls for new ideas and approaches for their obtaining. Among the number of advanced biotechnologies cell selection is one of the most ecologically positive. First, it is closed in vitro system that checks all parameters of cultivation; second, such system with the addition of chosen agents can guarantee the obtaining the genetically changed forms; third, obtained via cell selection cell cultures are able to sustain a number of stresses.

At the same time, as any method, the cell selection needs modifications and improvements. We proposed and realized the hypothesis about usefulness of cell selection with some heavy metal ions for obtaining plants tolerant to combinations of stress factors [1].

Heavy metal ions (HMI) belong to group of the most dangerous agents because their stress pressure can form vast alterations in different tissues of plant organism. Usually HMI act together with abiotic stresses and their joint effect is more hazardous. From another hand the resistance to HMI may be associated with such reaction to abiotic stresses. 
HMI are divided into two categories. They are - physiologically essential elements $\left(\mathrm{Cu}^{2+}, \mathrm{Zn}^{2+}, \mathrm{Co}^{2+}, \mathrm{Mo}^{6+}\right)$ and toxic at trace concentrations $\left(\mathrm{Cd}^{2+}, \mathrm{Pb}^{2+}, \mathrm{Ba}^{2+}, \mathrm{Hg}^{2+}, \mathrm{V}^{\mathrm{V}}, \mathrm{W}^{\mathrm{VI}}\right)$. We have obtained a number of tobacco cell lines resistant to lethal doses of $\mathrm{Cd}^{2+}, \mathrm{Ba}^{2+}, \mathrm{V}^{\mathrm{V}}, \mathrm{W}^{\mathrm{VI}}$. We have regenerants and $R_{1}$ seed progeny. Those plants are characterized by peculiar features of cellular metabolism during cultivation under stress conditions in vitro and in vivo. New tobacco forms challenged salt and water stresses [1]. Their tolerances were equal to the tolerances of natural halophytes and xerophytes.

There are many crops that suffered from osmotic stresses. So we expanded our approach for obtaining cell lines of soybean and wheat tolerant to osmotic stress. For this purpose barium cations $\left(\mathrm{Ba}^{2+}\right)$ were used.

Barium ions are investigated within the group of divalent cations with various effects. It was observed, that the presence of $\mathrm{Ba}^{2+}$ slightly decreased the initial proton pumping rate $\left(R_{0}\right)$ and slightly increased the membrane $\mathrm{H}^{+}$leakage (k1) [2]. The net extent proton translocation at steady state $\left(\delta_{\mathrm{s}}\right)$ was also decreased by $\mathrm{Ba}^{2+}$. At presence of inorganic phosphate $\mathrm{Ba}^{2+}$ stimulates malate-pyruvate and succinate oxidation [3]. Applying $\mathrm{Ba}^{2+}$ unilaterally to the root cap caused strong curvature away from the cation in some corn genotypes [4]. $\mathrm{Ba}^{2+}$ was more effective at $1 \mathrm{mM}$ than $5 \mathrm{mM}$, and maximum curvature was reached after about $2.5 \mathrm{~h}$. Curvature in response to unilateral application of $\mathrm{Ba}^{2+}$ to tips of decapitat roots was much weaker than that observed in intact roots. The scientific interest to $\mathrm{Ba}^{2+}$ ions is due to its interaction with $\mathrm{K}^{+}$cations too. It was shown that $\mathrm{Ba}^{2+}$ interrupted the $\mathrm{K}^{+}$inward transport $[5,6]$. Sometimes at $\mathrm{Ba}^{2+}$ presence there was observed the decline of $\mathrm{Na}^{+}$uptake and $\mathrm{K}^{+}$extrusion [7]. At the same time the negative action of salinity is expressed in drastic leakage of $\mathrm{K}^{+}[1,8,9]$.

The aim of the present investigation was to obtain cell lines of soybean (dicotyledon) and wheat (monocotyledon) tolerant to salinity via cell selection with $\mathrm{Ba}^{2+}$ ions.

\section{Materials and methods}

Cell cultures of soybean (Glycine max L. Merr variety Maryana) and wheat (Triticum aestivum L. variety Volodarka) were the objects of investigation.

Soybean calli cultures were initiated from leaves of aseptic young shoots cultivated in vitro. Initial wheat calli were obtained from immature embryos (14 days after artificial pollination). For callus induction and cultivation the B5 Gamborg nutritional medium with agar addition was used [10]. Those cultures (control, wild type) were bases for future cell selection. Suspension cultures were obtained by replacement calli cultures to liquid shake medium of the same contents for clusters disaggregation. Cell suspensions were grown in $300 \mathrm{ml}$ flasks containing $100 \mathrm{ml}$ per flask. The ratio cell biomass/medium $(w / v)$ was $1: 2$. The viability level of cell population was estimated according to [11]. The suspension for plating manipulation included $10 \mathrm{mg}$ of individual cell sediment per $100 \mathrm{ml}$ of liquid medium.

Selective media were created by the addition to B5 medium the lethal for wild type cell cultures doses of barium cations. $\mathrm{Ba}^{2+}$ dose that stopped 
the cells growth was the minimal. Under normal conditions such calli did not restore their development. (The correctness of such method was confirmed by soybean DNA analysis. The full degradation of DNA was observed after treatment of cell cultures or plants with HMI toxic concentrations [12].) Media for detecting the cell lines salt tolerance contained various types of salts: pure chemicals $-\mathrm{NaCl}, \mathrm{Na}_{2} \mathrm{SO}_{4}$, mixed substances - sea water salts. Those toxic agents were added at lethal concentrations too [1].

The initial selection of ion-resistant cell lines («plating») is a surviving and growth of single genetically changed cell variants under stress pressure. Cell suspensions $(0.5 \mathrm{ml})$ were plated in Petri dishes between two layers of selective solid media. Dishes were incubated at $25{ }^{\circ} \mathrm{C}$ and monitored for appearance of primary minicolonies. These colonies are considered to be ion-resistant cell lines. Ion-resistant colonies were cultivated for obtaining sufficient calli biomass during 3-4 passages. Further cultivations were performed under changed conditions: normal nutrition - B5 medium; stressful environment $-\mathrm{B} 5$ medium with the addition of toxic matters $\left(\mathrm{Ba}^{2+}\right.$ cations, salts). Besides, the medium rotations were arbitrary.

During cultivation variants tolerance levels were evaluated. As a growth marker calli relative fresh mass growth $(\Delta m)$ was used:

$$
\Delta \mathrm{m}=\left(m_{f}-m_{i}\right) / m_{i}
$$

where $m_{i}-$ initial biomass weight at the start of the passage; $m_{f}-$ final biomass weight at the end of the passage [13].

$\mathrm{Na}^{+}$and $\mathrm{K}^{+}$content was determined in fresh tissues by atomic absorption spectrophotometry (Perkin-Elmer 1100B spectrophotometer, Norwalk, CT, USA) according [14].

Data of relative fresh mass growth $(\Delta m)$ are statistically analyzed. Data shown are the average of three replicates $\pm \mathrm{SE}$.

\section{Results and discussion}

Several approaches to obtaining salt tolerant cell variants are developed. We propose simple one that does not require long chain selective manipulation. Moreover, our method provides the selection of genetically changed cultures with combined stress tolerance.

On selective media with lethal doses of barium cations resistant cell lines (Ba-RCL) of soybean and wheat were obtained. Figure (1-5) illustrates the protocol stages of soybean resistant variants selection.

For both cultures a colony diameter was not larger than $0.5 \mathrm{~cm}$. Cell variants that maintained growth were transferred to basal B5 medium and were cultivated under normal conditions within 2-4 passages (duration of 1 passage was 30-35 days). After biomass increasing ion-resistant cell lines were tested under various stress conditions.

The salt toxicity combined harmful effect of definite ions and disturbance caused by lowered external water potential. Sodium sulfate - is pure chemical, while sea water salts combines several ions. The addition of the first agent creates the sulfate salinity; the presence of the second matter provides the sulfate-chloride salinity (Table 1,2).

There was fixed that the relative fresh mass growth $(\Delta \mathrm{m})$ measured during resistant variants cultivation at presence of $\mathrm{Ba}^{2+}$ was the smallest. 

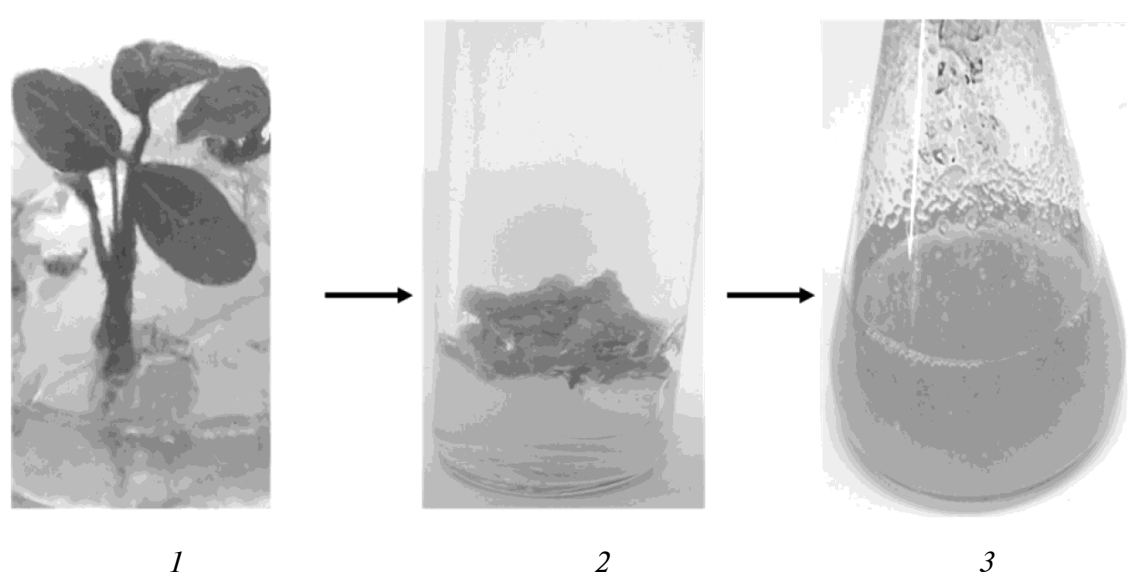

PLATING PROCEDUFRE
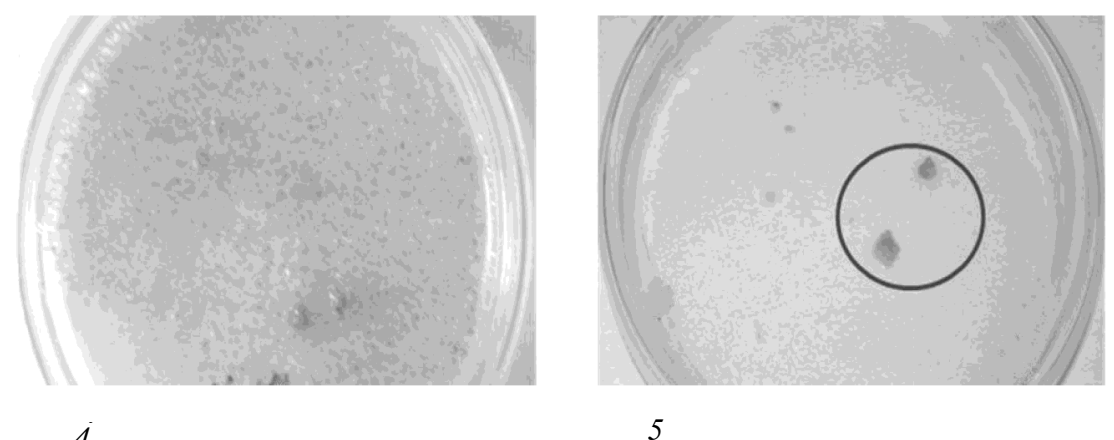

5

Cell selection with barium cations for obtaining salt tolerant cell lines:

1 - soybean plant cultivated in vitro; source of primary explants; 2 - the induction and development of initial plant cell cultures (wild type), dedifferentiation; 3 - cell suspension culture prepared for cell selection manipulations; 4, $5-$ minicolonies appeared on Petri dishes $(4-$ normal conditions, $5-$ resistant variants which survive under lethal stress pressure)

Ba-RCL grew under lethal salt pressure. Control cell cultures died at the end of single passage. Compared to normal conditions calli relative fresh mass growth $(\Delta m)$ of both resistant cultures decreased under salinity. This event was observed earlier [1, 5, 10]. Hasegawa at al. [8] interpreted this fact as peculiar feature of salt-adapted cultures. Little fresh weight was due to small cells. Adapted cultures developed osmotic adjustment in such manner [5].

In accordance with $\triangle \mathrm{m}$ parameter Ba-RCL demonstrated various levels of salt tolerance (Table 1,2). Probably it is concerned with aniontolerance.

To understand how Ba-RCL maintain cation balance under stress conditions $\mathrm{K}^{+} / \mathrm{Na}^{+}$ratio was estimated (Table 3 ).

The cytosolic $\mathrm{K}^{+}$and $\mathrm{Na}^{+}$contents are regulated by inner compartmentation and efflux of those cations. It is clear that $\mathrm{K}^{+} / \mathrm{Na}^{+}$ratios in both cells cultures, cultivated without stress (B5 medium), expressed normal ion 
CELL SELECTION WITH HEAVY METAL IONS

TABLE 1. Relative fresh mass growth ( $\triangle \mathrm{m})$ of soybean Ba-resistant cell lines (Ba-RCL)

\begin{tabular}{c|c|c|c|c}
\hline \multirow{2}{*}{ Variant } & \multicolumn{4}{|c}{$\Delta m$} \\
\cline { 2 - 5 } & $\begin{array}{c}\text { B5, normal } \\
\text { conditions }\end{array}$ & $\mathrm{B} 5+\mathrm{Ba}^{2+}$ & $\begin{array}{c}\text { B5 + sea water } \\
\text { salts }\end{array}$ & $\mathrm{B} 5+\mathrm{Na}_{2} \mathrm{SO}_{4}$ \\
\hline Ba-RCL № 1 & $6.63 \pm 0.24$ & $1.87 \pm 0.19$ & $2.55 \pm 0.65$ & $2.98 \pm 0.14$ \\
Ba-RCL № 2 & $7.08 \pm 0.49$ & $2.66 \pm 0.09$ & $3.09 \pm 0.27$ & $3.25 \pm 0.12$ \\
Ba-RCL № 5 & $5.25 \pm 0.1$ & $2.15 \pm 0.03$ & $3.76 \pm 0.42$ & $4.12 \pm 0.11$ \\
Wilde type & $5.93 \pm 0.44$ & elimination & elimination & elimination \\
\hline
\end{tabular}

TABLE 2. Relative fresh mass growth ( $\triangle m)$ of wheat Ba-resistant cell lines (Ba-RCL)

\begin{tabular}{c|c|c|c|c}
\hline \multirow{2}{*}{ Variant } & \multicolumn{4}{|c}{$\Delta m$} \\
\cline { 2 - 5 } & $\begin{array}{c}\text { B5, normal } \\
\text { conditions }\end{array}$ & $\mathrm{B} 5+\mathrm{Ba}^{2+}$ & $\begin{array}{c}\mathrm{B} 5+\text { sea water } \\
\text { salts }\end{array}$ & $\mathrm{B} 5+\mathrm{Na}_{2} \mathrm{SO}_{4}$ \\
\hline Ba-RCL № 1 & $1.53 \pm 0.09$ & $1.39 \pm 0.18$ & $0.36 \pm 0.07$ & $0.09 \pm 0.01$ \\
Ba-RCL № 2 & $0.73 \pm 0.15$ & $0.54 \pm 0.10$ & $0.25 \pm 0.02$ & $0.33 \pm 0.02$ \\
Ba-RCL № 3 & $0.46 \pm 0.06$ & $0.39 \pm 0.03$ & $0.14 \pm 0.04$ & $0.29 \pm 0.02$ \\
Wilde type & $2.05 \pm 0.29$ & elimination & elimination & elimination \\
\hline
\end{tabular}

TABLE 3. $\mathrm{K}^{+} / \mathrm{Na}^{+}$ratios of Ba-resistant cell lines (Ba-RCL), cultivated on selective media

\begin{tabular}{c|c|c|c|c}
\hline \multirow{2}{*}{ Variant } & \multicolumn{5}{c}{$\mathrm{K}^{+} / \mathrm{Na}^{+}$ratio } \\
\cline { 2 - 5 } & $\begin{array}{c}\text { B5, normal } \\
\text { conditions }\end{array}$ & $\mathrm{B} 5+\mathrm{Ba}^{2+}$ & $\begin{array}{c}\mathrm{B} 5+\text { sea water } \\
\text { salts }\end{array}$ & $\mathrm{B} 5+\mathrm{Na}_{2} \mathrm{SO}_{4}$ \\
\hline \multicolumn{5}{c}{ Soybean } \\
Ba-RCL № 1 & 5.58 & 9.25 & 0.71 & 0.48 \\
Ba-RCL № 2 & 6.28 & 10.37 & 0.68 & 0.44 \\
Ba-RCL № 1 & 5.96 & Wheat & 0.56 & 0.44 \\
\hline
\end{tabular}

homeostasis and were due to low $\mathrm{Na}^{+}$concentration in the external nutrition medium. But the elevated $\mathrm{K}^{+} / \mathrm{Na}^{+}$ratios in calli that grew at presence of barium cations are the direct impact of those cations on potassium extrusion. There were detected that $\mathrm{K}^{+}$and $\mathrm{Na}^{+}$influxes can be separated into two general categories. One has higher affinity for $\mathrm{K}^{+}$over $\mathrm{Na}^{+}$the second demonstrates lower $\mathrm{K}^{+} / \mathrm{Na}^{+}$selectivity [15-17]. There are two classes of $\mathrm{K}^{+}$selective channels: one inward (IRC) and one outward (ORC). Both were blocked by $\mathrm{Ba}^{2+}[18]$. We have observed that RFG of soybean Ba-resistant lines cultivated on medium with $\mathrm{Ba}^{2+}$ addition was the lowest while this parameter of wheat cultures under same conditions was the highest. We can suppose that these events are peculiar features of monocots and dicots. The differences in $\mathrm{K}^{+}$transport in cells may expresses in such manner.

$\mathrm{K}^{+} / \mathrm{Na}^{+}$ratios were low in calli, cultivated on both salt-containing media. At the same time the $\Delta \mathrm{m}$ parameter was positive. So the salt tolerance of Ba-resistant lines was not concerned with $\mathrm{K}^{+}$efflux/accumulation. 
The salinity toxicity develops disruption of ionic homeostasis due to accumulation of harmful $\mathrm{Na}^{+}$and $\mathrm{Cl}^{-}$ions. Evolution create a number of ways to prevent sodium accumulation in the cytoplasm that include minimizing $\mathrm{Na}^{+}$influx, intracellular compartmentation of $\mathrm{Na}^{+}$and maximizing $\mathrm{Na}^{+}$efflux via $\mathrm{Na}^{+} / \mathrm{H}^{+}$antiporters in the plasma membrane [8, 14]. Vacuolar compartmentation of $\mathrm{Na}^{+}$has the effect of decreasing cell water potential [8].

The revealing of the mechanisms which maintain salt tolerance lead plant scientist to search for models of investigation such as Arabidopsis thaliana and Thellungiella halophila. In contrast with former the latter tolerates extreme salinity [19, 20]. Thellungiella and Arabidopsis differ in both uptake and release of potassium ions into/from leaf epidermal cell in high salinity. Transporters for uptake of $\mathrm{K}^{+}$, export of $\mathrm{Na}^{+}$and compartmentation of both ions play important roles in Thellungiella's exceptional ability to control cellular and tissue ion homeostasis [20].

We have obtained glycophyte-derived plant cell lines which survive under lethal for wild type cultures salinity. Those variants have retained salt tolerance after several passages under salt-free conditions. We can suppose that this trait is developed on significant cellular basis. At the same time under salinity their $\mathrm{K}^{+} / \mathrm{Na}^{+}$ratios revealed active sodium accumulation. So those variants were osmotically adjusted cultures. Probably cells correct the osmotic imbalance by inner ions redistribution/compartmentation. This event we observed during investigation of tobacco salt resistant cell lines [1]. The vacuolar compartmentation of $\mathrm{Na}^{+}$and $\mathrm{Cl}^{-}$ions and subsequent osmotic adjustment in the cytoplasm by several compatible osmoticalliactive substances are widely observed in tolerant plants [8]. Amino acid proline is a well-known organic molecule involved in osmotic protection. It is associated with the salt tolerance.

The contents of free proline were measured in calli of tolerant wheat and soybean lines during cultivation under various conditions: salt-free medium (B5, control), ion-containing medium $\left(\mathrm{Ba}^{2+}\right)$, salinity (sea water salts, $\left.\mathrm{Na}_{2} \mathrm{SO}_{4}\right)$ [21, 22]. The levels of free proline correlated with the media types. The cells cultivated without addition of stress agents and at presence of barium ions accumulated lowest amounts of this amino acid. Salt media stimulated the free proline accumulation. The highest levels of proline were observed in both soybean and wheat Ba-resistant variants cultivated at presence of sea water salts.

The mechanisms which provide salt tolerance to cultured in vitro cells and molecular processes by which cells maintain viability in saline environments are not completely understood. A progress in this area has been made by obtaining and studying glycophyte-derived cell cultures. A number of such variants are adaptive forms that achieved the trait in long term tissue cultures. But several passages under normal conditions detect physiological basis of their tolerance. Another type of tolerant cultures does not require prior adaptation to express considerable tolerance to salinity. The basis of such tolerance is concerned with their genetic characteristics (changes).

Tolerant forms with peculiar physiology and metabolism obtained via modern biotechnology encourage better understanding intercellular interactions. The creation of adequate selective system is a good chance for it. 
We obtained soybean and wheat cell lines with combined tolerance to ion and osmotic stresses. Salt-treated cultures are characterized by increased levels of sodium and proline. Vacuolar ion compartmentation followed by proline level elevation is effective mechanism of salt tolerance.

$\mathrm{Ba}^{2+}$-Stressed calli accumulated potassium. Probably this phenomenon is maintains by $\mathrm{Ba}^{2+} / \mathrm{K}^{+}$interaction. The study of ion transporters and their cooperation will be a topic of future investigations. We can assume that combined stress resistance concern with different protective mechanisms.

Tissue culture is a method of growing forms as undifferentiated cells. Those cells can divide indefinitely in vitro and in many cases be induced to regenerate to whole plants. Regeneration of plant from wild type callus cultures is becoming routine procedure. At the same time regeneration manipulations are objects of permanent improvements. The media rotations are developing for regeneration. The induction of this procedure requires to control cytokinin/auxin ratios. Various types of carbohydrates, their doses are necessary for the initiation of regeneration. Parental genotypes are very important in the ability to identify embryogenic callus. At the same time there were observed that regeneration potential significantly decrease in long-term stable cell cultures.

To confirm and investigate cellular stress tolerance the long-term cultivation is necessary. So the successful regeneration from tolerant cell lines is exclusive event. Today we have no success in plant regeneration from our soybean and wheat cell lines. However, if the aims of research for salt stress tolerance in plant cell cultures are to create salt tolerant crops, then availability of genomes containing the information for integrated cellular reaction to salt stress, can represent a valuable genetic basis. We suppose the cell selection with heavy metal ions makes contribution to agricultural plant breeding. The knowledge of plant stress tolerance will increase.

\section{REFERENCES}

1. Sergeeva, L.E. (2013). Cell selection with heavy metal ions for obtaining plant genotypes with combined resistance to abiotic stresses. Kiev: Logos [in Russian].

2. Tu, S.-I., Nungesser, E. \& Brauer, D. (1989). Characterization of the effect of divalent cations on the coupled activities of the $\mathrm{H}^{+}$-ATPase in tonoplast vesicles. Plant Physiol., 90, pp.1636-1643.

3. Miller, R.J., Dumford, S.W., Koeppe, D.E. \& Hanson, J.B. (1970). Divalent cation stimulation of substrate oxidation by corn mitochondria. Plant Physiol., 45, pp. 649-653.

4. Hasenstein, K.H., Evans, M.L., Stinemetz, C.L., Moore, R., Fondrren, M., Koon, C., Higby, M. \& Smucker, A.J.M. (1988). Comparative effectiveness of metal ions in inducing curvature in primary roots of Zea mays. Plant Physiol., 86, pp. 885-889.

5. Fan, L.M., Wu, W.-H. \& Yang, Y.-Y. (1999). Identification and characterization the inward $\mathrm{K}^{+}$channel in the plasma membrane Brassica pollen protoplasts. Plant Cell Physiol., 40 (8), pp. 859-865.

6. Rubio, F., Nieves-Cordones, M., Aleman, F. \& Martinez, V. (2008). Relative contribution of AtHAK5 and AtHAK1 to $\mathrm{K}^{+}$uptake in the high affinity range of concentrations. Physiol. Plant., 134, pp. 598-608.

7. Wang, D.-M., Zhang, J.-L. \& Flowers, T.J. (2007). Low affinity $\mathrm{Na}^{+}$uptake in the halophyte Suaeda maritima. Plant Physiol., 145, pp. 559-571.

8. Hasegawa, P.M., Bressan, R.A., Zhu, J.K. \& Bohnert, H.J. (2000). Plant cellular and molecular responses to high salinity. Annu. Rev. Plant Physiol. Plant Mol. Biol., 51, pp. 463-499. 
9. Razavizadeh, R. \& Ehsanpour, A.A. (2009). Effects of salt stress on proline content, expression of delta-1-pyrroline-5-carboxilate synthetase, activities of catalase and ascorbate peroxidase in transgenic tobacco plants. Biol. Lett., 46 (2), pp. 63-75. https:// doi.org/10.2478/v10120-009-0002-4

10. Gamborg, J.L., Miller, R.A. \& Ojima, K. (1968). Nutrient requirement of suspension cultures of soybean roots. Exp. Cell Res., 509, pp. 151-158.

11. Conner, A.J. \& Meredith, C.P. (1985). Large scale selection of aluminum-resistant mutants from plant cell culture: expression and inheritance in seedlings. Theor. Appl. Genet., 71, pp. 159-165.

12. Mykhalska, S.I., Sergeeva, L.E. \& Tishchenko, E.N. (2010). Cytogenetical analysis of soybean tungsten-resistant cell line. Fiziol. biokhim. kult. rastenii, 42, No. 2, pp. $125-$ 131 [in Russian].

13. Maliga, P. (1984). Isolation and characterization of mutants in plant cell culture. Ann. Rev. Plant Physiol., 35, pp. 519-542.

14. Kant, S., Kant, P., Rahen, E. \& Barak, S. (2006). Evidence that differential gene expression between the halophyte Thellungiella halophila and Arabidopsis thaliana is responsible for higher levels of the compatible osmolyte proline and tight control of $\mathrm{Na}^{+}$uptake in T. halophila. Plant Cell Environ., 29, pp. 1220-1234. https://doi.org/10.1111/j. 1365.3040.2006.01502.

15. Tester, M. \& Davenport, R. (2003). $\mathrm{Na}^{+}$and $\mathrm{Na}^{+}$transport in higher plants. Ann. Bot., 91, pp. 503-527.

16. Demidchik, V. \& Tester, M. (2002). Sodium fluxes through nonselective cation channels in the plasma membrane of protoplasts from Arabidopsis roots. Plant Physiol., 128, pp. 379-387.

17. Arend, M., Stinzing, A., Wind, C., Langer, K., Latz, A., Ache, P., Fromm, J. \& Hedrich, R. (2005). Polar-localised popla $\mathrm{K}^{+}$channel capable to controlling electrical properties of wood-forming cells. Planta, 223, pp. 140-148.

18. Maathuis, F.J.M., Filatov, V., Herzyk, P., Krijer, G.C., Axelsen, K.B., Chen, S., Green, B.J., Madagan, K.L., Sanchez-Fernandez, R. \& Forde, B.G. (2003). Transcriptome analysis of root transporters reveals participation of multiple gene families in the response to cation stress. Plant J., 35, pp. 675-692.

19. Volkov, V., Wang, B., Dominy, P.J., Fricke, W. \& Amtmann, A. (2004). Thellungiella halophila, a salt-tolerant relative of Arabidopsis thaliana, possesses effective mechanisms to discriminate between potassium and sodium. Plant Cell Environ., 27, pp. 1-14.

20. Amtmann, A., Bohnert, H.J. \& Bressan, R.A. (2005). Abiotic stress and plant genome evolution. Search for new models. Plant Physiol., 138, pp. 127-130.

21. Sergeeva, L.E \& Bronnikova, L.I. (2017). Cell selection with $\mathrm{Ba}^{2+}$ cations for obtaining salt resistant wheat lines. Fiziol. rast. genet., 49, No. 2, pp. 174-178 [in Russian].

22. Mykhalskaya, S.I. \& Sergeeva, L.E. (2007). Free proline content of soybean cell lines cultivated under stress pressure of various agents. Visn. ukr. tov. genet. selec., No. 1-2, pp. 33-38 [in Russian].

Received 13.06.2019

\section{КЛЕТОЧНАЯ СЕЛЕКЦИЯ С ИОНАМИ ТЯЖЕЛЫХ МЕТАЛЛОВ ДЛЯ ПОЛУЧЕНИЯ СОЛЕУСТОЙЧИВЫХ РАСТИТЕЛЬНЫХ КЛЕТОЧНЫХ КУЛЬТУР}

\section{Л.Е. Сергеева, С.И. Михальская}

Институт физиологии растений и генетики Национальной академии наук Украины

Предложен метод клеточной селекции с ионами тяжелых металлов для отбора солеустойчивых клеточных линий растений. На селективных средах, содержащих летальные для клеточных культур дикого типа дозы катионов $\mathrm{Ba}^{2+}$, получены клеточные варианты сои и пшеницы. Отобранные клоны тестировали на фоне действия различных стрессовых агентов: ионы $\mathrm{Ba}^{2+}$, соли морской воды, сульфат натрия. Устойчивые клетки выдерживали любой тип летального стресса. Каллюс сохранял солеустойчивость после культивирования на бессолевой среде в течение ряда пассажей. При куль- 
тивировании на солевом фоне в клетках отмечали низкое соотношение $\mathrm{K}^{+} / \mathrm{Na}^{+}$и существенную аккумуляцию свободного пролина. Высказано предположение о том, что комплексная стрессоустойчивость связана с реализацией различных механизмов устойчивости.

Ключевые слова: соя, пшеница, клеточная селекция, катионы $\mathrm{Ba}^{2+}$, солеустойчивость.

\section{КЛІТИННА СЕЛЕКЦІЯ 3 ІІОНАМИ ВАЖКИХ МЕТАЛІВ ДЛЯ ОТРИМАННЯ СОЛЕСТіЙКИХ РОСЛИННИХ КЛІТИННИХ КУЛЬТУР}

\section{Л.Є. Сергєєва, С.І. Михальська}

Їнститут фізіології рослин і генетики Національної академії наук України

Запропоновано метод клітинної селекції з іонами важких металів для відбору солестійких ліній рослин. На селективних середовищах, які містили летальні для клітинних культур дикого типу дози катіонів $\mathrm{Ba}^{2+}$, отримано клітинні варіанти сої та пшениці. Відібрані клони тестували за умов дії різних стресових чинників: іони $\mathrm{Ba}^{2+}$, солі морської води, сульфат натрію. Стійкі клітини витримували будь-який тип летального стресу. Калюс зберігав солестійкість після культивування на безсольовому середовищі впродовж кількох пасирувань. При культивуванні за умов засолення у клітинах відмічали низьке співвідношення $\mathrm{K}^{+} / \mathrm{Na}^{+}$та істотну акумуляцію вільного проліну. Висловлено припущення, що комплексна стійкість пов'язана з реалізацією різних механізмів стійкості.

Ключові слова: соя, пшениця, клітинна селекція, катіони $\mathrm{Ba}^{2+}$, солестійкість. 